\title{
Pembangunan Aplikasi Web dan Mobile Sistem Informasi Webinar di Era New Normal
}

\author{
Hafid Yoza Putra, ${ }^{a}{ }^{*}$, Hafizah Hanim ${ }^{a}$, Afriyanti Dwi Kartika ${ }^{a}$ \\ a Jurusan Sistem Informasi,Fakultas Teknologi Informasi, Universitas Andalas, 25163, Indonesia
}

\section{INFORMASI ARTIKEL}

Sejarah Artikel:

Diterima Redaksi: 18 Juli 2020

Revisi Akhir: 05 September 2020

Diterbitkan Online: 11 November 2020

\section{KATA KUNCI}

Webinar,

Covid-19,

New Normal,

Aplikasi Web,

Aplikasi Mobile,

\section{KORESPONDENSI}

E-mail: hafid@it.unand.ac.id*

\begin{abstract}
A B S S T R A C $\mathbf{C}$
Pemanfaatan internet terus meningkat ditengah pandemi Covid-19. Berbagai kalangan diharuskan tetap bekerja dan belajar dari rumah dengan memanfaatkan internet dan teknologi informasi. Larangan untuk mengumpulkan orang dalam jumlah besar pada satu lokasi membuat kegiatan seminar tidak dapat dilaksanakan. Hal tersebut membuat webinar ramai diminati. Namun, dari sudut pandang penyelenggara webinar, diperlukan suatu sistem yang dapat mempermudah dan membantu dalam menyelenggarakan sebuah seminar online. Metode penelitian yang digunakan adalah metode waterfall. Metode memiliki empat tahap seperti analisis, desain, code dan tes. Pengujian aplikasi menggunakan metode blackbox testing. Aplikasi web dibangun menggunakan framework laravel. Aplikasi mobile dibangun menggunakan android studio. Aplikasi memiliki lima belas fungsional dengan dua orang aktor. Hasil pengujian membuktikan bahwa semua fungsional berjalan sesuai dengan semana mestinya. Aplikasi ini diharapkan dapat menjadi solusi untuk pengelolaan kegiatan webinar di Era New Normal akibat dari pandemi Covid-19.
\end{abstract}

\section{PENDAHULUAN}

Pemanfaatan internet oleh masyarakat Indonesia telah mengalami kenaikan dari tahun ke tahun dan meningkat sebanyak $10.12 \%$ pada tahun 2019 [1] . Pemanfaatan internet ini telah digunakan untuk berbagai bidang, seperti untuk keperluan bisnis, pendidikan, marketing, pariwisata dan masih banyak lainnya [2]. Pemanfaatan internet ini terus meningkat terutama dengan hadirnya pandemi Covid-19 telah memaksa berbagai kalangan untuk memanfaatkan internet dan teknologi informasi untuk tetap bekerja dan belajar tanpa harus keluar dari rumah [3]

Pandemi Covid-19 melahirkan banyak tradisi baru diberbagai aspek kehidupn. Salah satunya akibat larangan mengumpulkan orang dalam jumlah besar pada satu lokasi membuat kegiatan seminar tidak dapat dilaksanakan. Hal tersebut menjadi faktor ramainya peminat Webinar [4]. Webinar merupakan metode pendidikan e-learning untuk mendengarkan, mengamati, dan berpartisipasi dalam presentasi suatu topik tertentu [5][6]. ELearning merupakan istilah webinar mengacu kepada perpaduan kata "web" dan "seminar" di mana kegiatan seminar dilaksanakan secara virtual melalui media online [7][8]. Webinar merupakan salah satu bukti dampak peningkatan teknologi dalam bidang pendidikan [2]. Webinar dapat digunakan untuk peningkatan pembelajaran jarak jauh[9].

Kehadiran webinar di masa pandemi ini telah menghadirkan berbagai persepsi bagi peserta webinar [5], seperti webinar lebih ekonomis dan memberikan kemudahan untuk berbagi informasi lintas profesi dan instansi, pelaksanaan webinar pada kapan dan dimana saja. Selain itu, webinar secara keseluruhan berjalan dengan baik, suara pemateri jelas didengar oleh peserta. Webinar juga sangat mudah dilaksanakan, mulai dari pengumuman, pengumpulan peserta, pelaksananaan bahkan pendistribusian esertifikat [5][10][11]. 
Penelitian sejenis pembangunan aplikasi webinar yang telah dilakukan oleh [11] menghasilkan aplikasi dengan fungsional melihat waktu, lokasi dan biaya seminar; mengetahui namanya sudah terdaftar atau belum; dan dapat menghitung pemasukkan dari peserta. Penelitian yang dilakukan oleh [12] memiliki fungsional login, mengelola data user, rekap data peserta, dan pembayaran biaya seminar. Pembangunan aplikasi webinar untuk pembinaan wirausaha baru [13] memiliki fungsional otentikasi pengguna, menampilkan materi seminar, pengelolaan materi, melakukan obrolan dengan peserta dan memberikan pelaksanaan webinar pada peserta. Hasil penelitian yang dilakukan oleh [14] adalah aplikasi yang dapat memudahkan peserta seminar untuk mengunduh e-sertifikat secara mandiri yang telah dilengkapi nama masing-masing peserta. Aplikasi ini memudahkan distribusi e-sertifikat dan tanpa terkendala jarak di era pandemi Covid-19. Perancangan aplikasi smart seminar [15] memiliki fungsional menampikan informasi terkait pengumuman, pendaftaran acara, absen kehadiran, dan peserta dapat mengirimkan pertanyaan.

Namun, dari sudut pandang penyelenggara webinar, diperlukan suatu sistem yang dapat membantu penyelenggaraan sebuah seminar online. Sistem informasi ini dibutuhkan untuk menyediakan informasi tentang webinar yang diadakan, mengelola data peserta dan pemateri, pendistribusian modul dan e-sertifikat, penomoran e-sertifikat secara otomatis, check-in kehadiran, notifikasi email, laporan kegiatan webinar dan juga memvisualisasikan data sehingga kinerja webinar dapat diukur. Hingga saat ini beberapa Sistem informasi Webinar masih sebatas menyediakan kemudahan akses informasi seminar online. Oleh karena itu kami melakukan penelitian ini yang bertujuan untuk membantu penyelenggara webinar dalam melakukan pra, pasca dan saat event webinar berlangsung. Tidak hanya memberi kemudahan bagi pihak pelaksana, namun peserta seminar juga mendapatkan keuntungan dari kemudahan akses informasi mengenai seminar yang diadakan, modul atau materi seminar, absesnsi, hingga sertifikat yang dapat diunduh secara mandiri. Berdasarkan hal tersebut dilakukan penelitian dengan judul "Pembangunan Aplikasi Web dan Mobile Sistem Informasi Webinar di Era New Normal". Penelitian ini akan berkontribusi sebagai sarana konstribusi akademisi Unand dalam melawan wabah Coronavirus yang sedang melanda dunia saat sekarang ini, khususnya Indonesia.

\section{METODE}

\subsection{Objek Penelitian}

Objek penelitian adalah seminar dan pelatihan secara offline pada Universitas XYZ. Pemilihan objek penelitian ini dikarenakan disana sering dilakukan kegiatan seminar dan pelatihan. Sebelumnya kegiatan tersebut masih dilakukan tanpa adanya sistem informasi yang memudahkan pengelolaan webinar, namun hal itu tidak memungkinkan untuk dilakukan pada masa pandemi sekarang ini. Sehingga diperlukan suatu aplikasi sistem informasi untuk memanajemen seluruh proses yang terjadi pada sistem secara online.
Metode pengumpulan data dengan studi lapangan untuk mengobservasi, wawancara stakeholder dan analisis dokumen terkait. Observasi dilakukan dengan mengamati alur penyelenggaraan seminar, perlengkapan yang digunakan, serta cara kerja aktor pada system. Wawancara dengan memberikan pertanyaan terkait proses bisnis seminar yang sedang berjalan, kepada staff yang mengelola kegiatan seminar. Analisis dokumen dengan mencari, mengumpulkan dan mempelajari dokumen yang berhubungan dengan sistem. Studi literatur dengan mencari dan menganalisis penelitian terkait dengan pembangunan aplikasi webinar.

\subsection{Metode Pembangunan Sistem}

Metode pembangunan sistem adalah metode waterfall. Metode ini merupakan model linear yang memiliki tahapan pengembangan system yang berurutan : analisis, desainn, kode, dan tes [16]. Model ini sering digunakan dalam pembangunan suatu sistem atau perangkat lunak yang bersifat generic. Setiap tahapan harus diselesaikan sebelum dapat lanjut mengerjakan tahapan berikutnya[17]. Metode waterfall dapat dilihat pada Gambar 1.

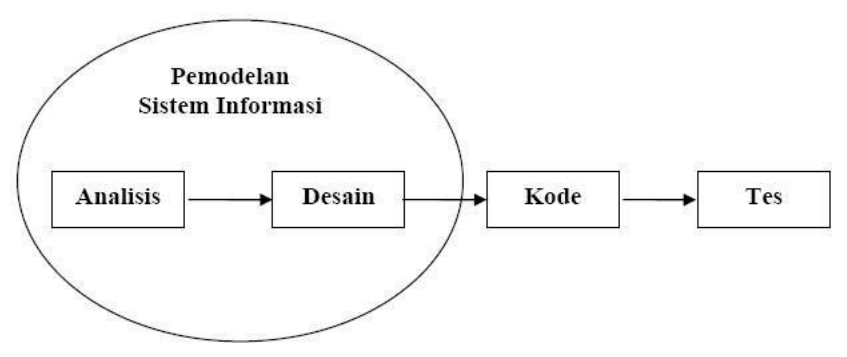

Gambar 1. Metode Waterfall [16].

Berikut merupakan penjelasan dari masing-masing tahapan pada metode waterfall:

a) Analisis

Tahap ini adalah tahap untuk mengidentifikasi permasalahan di Universitas XYZ terkait proses penyelenggaraan seminar, kemudian dilanjutkan dengan analisa dan evaluasi. Kemudian analisa terhadap kebutuhan untuk pengembangan aplikasi.

b) Desain

Tahap ini meliputi perencanaan setiap kebutuhan yang dibedah pada tahap sebelumnya. Perancangan tersebut terdiri dari perancangan ERD (Entity Relational Diagram), perancangan antarmuka menggunakan UML dan arsitektur aplikasi. Kemudian penulis merancang tampilan antarmuka pada sistem informasi berbasis web dan mobile.

c) Kode

Program komputer yang dibangun menghasilkan dua model aplikasi, yaitu berbasis web dan mobile. Aplikasi berbasis web dibuat menggunakan pemrograman PHP pada framework Laravel. Model aplikasi berbasis mobile dibangun dengan menggunakan tool Android Studio sebagai media pada platform Android.

\section{d) Testing}

Pengujian untuk membuktikan sistem telah memenuhi dan sesuai dengan kebutuhan yang diharapkan.

\subsection{Metode Pengumpulan Data}




\section{HASIL}

\subsection{BPMN}

Proses bisnis dari sistem informasi webinar yang diusulkan dimodelkan dengan Business Process Model and Notation untuk selanjutnya dilakukan analisis sistem. Model tersebut dapat dilihat pada Gambar 2.

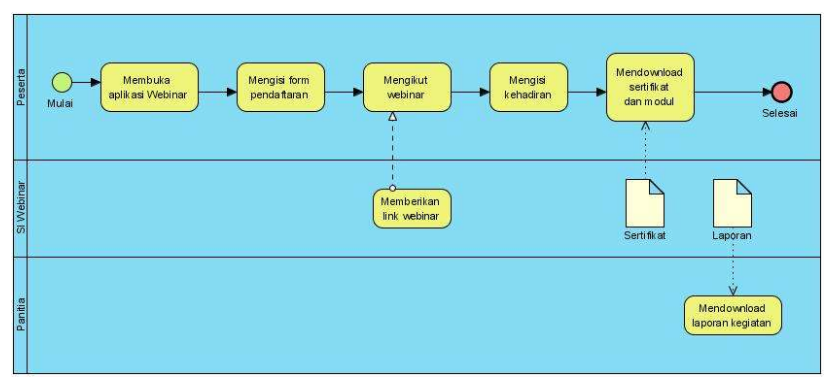

Gambar 2. BPMN sistem yng diusulkan

Berikut ini penjelasan sistem yang diusulkan:

1.Peserta membuka aplikasi Webinar

2.Peserta mengirim form pendaftaran

3.Sistem membrikan link webinar

4.Peserta mengikuti seminar

5.Peserta mengisi kehadiran

6.Peserta mendownload sertifikat dan modul seminar

7.Panitia mendownload laporan kegiatan seminar

\subsection{Kebutuhan Fungsional}

Berdasarkan analisis alur proses penyelenggaraan seminar, dapat dirumuskan beberapa kebutuhan fungsionalitas yaitu :

1.Peserta dapat melihat daftar kegiatan webinar yang tersedia.

2.Peserta dapat melakukan pendaftaran pada webinar yang dipilih.

3.Peserta dapat melihat link webinar yang telah didaftarkan.

4.Peserta dapat melakukan check in kehadiran.

5.Peserta dapat unduh modul webinar.

6. Peserta dapat unduh sertifikat

7. Admin dapat login.

8. Admin dapat mengelola kegiatan webinar.

9. Admin dapat melihat daftar peserta yang telah mendaftar.

10. Admin dapat melihat daftar peserta yang hadir.

11. Admin dapat mengelola waktu presensi.

12. Admin dapat mengelola waktu unduh modul dan sertifikat.

13. Admin dapat unggah dan mengelola sertifikat webinar.

14. Admin dapat mencetak laporan kegiatan webinar.

15. Admin dapat mengirimkan reminder dan link webinar melalui email kesemua peserta terdaftar.

\subsection{Use Case Diagram}

Semua fungsional pada sistem merupakan proses yang secara teknis dikerjakan oleh para aktor yang terlibat. Hubungan antara fungsional dan aktor yang terlibat dapat digambarkan menggunakan use case diagram, dapat dilihat pada Gambar 3 .

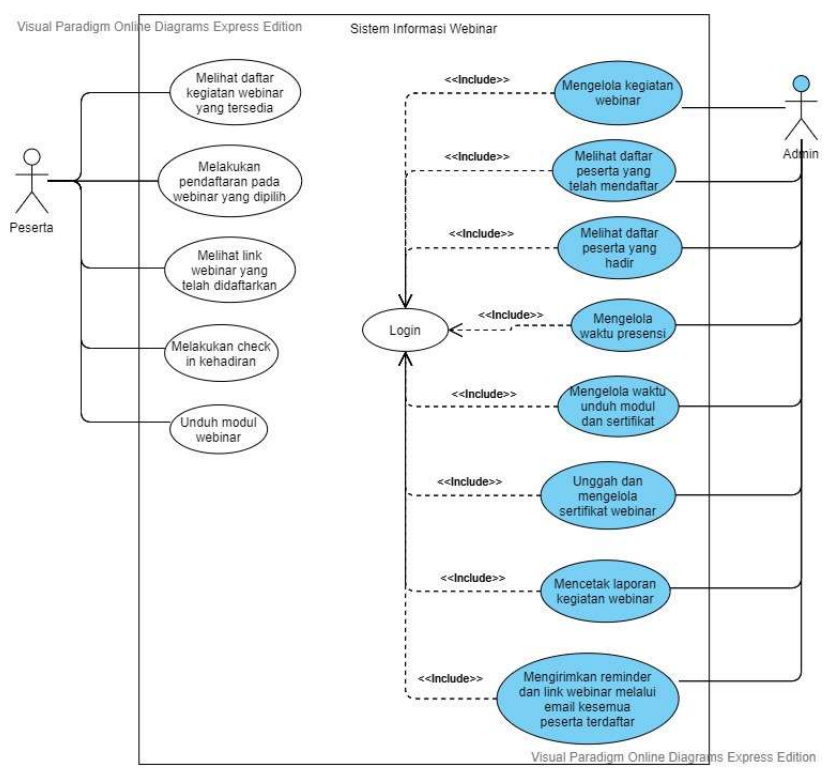

Gambar 3. Use case diagram

Lima belas fungsionalitas pada aplikasi web yang memiliki keterkaitan dengan masing-masing aktor. Aktor peserta memiliki enam fungsional, yaitu melihat webinar, mendaftar webinar, melihat link webinar, check-in kehadiran, mengunduh modul, dan mengunduh sertifikat. Aktor admin memiliki sembilan fungsional, yaitu mengelola webinar, melihat peserta terdaftar, melihat peserta yang hadir, melihat persebaran peserta, mengelola waktu kehadiran, mengelola waktu unduh, mengunggah modul, dan mengunggah sertifikat.

\subsection{Use Case Scenario}

Use case scenario unduh sertifikat merupakan salah satu alur proses yang dapat dilakukan oleh peserta, dapat dilihat pada Tabel 1.

Use case scenario tersebut digunakan untuk menjelaskan salah satu fungsional yang terdapat pada use case diagram. Aktor dapat mengunduh sertifikat dengan syarat aktor tersebut telah berhasil mendaftar pada webinar tersebut dan telah melakukan check-in kehadiran pada aplikasi. Aktor mengklik menu webinarkan, lalu memasukkan alamat email yang didaftarkan. Sistem akan menampilkan informasi berupa daftar webinar yang akan datang dan yang telah diikuti. Pada setiap informasi tersebut, disediakan link untuk mengunduh sertifikat. Aktor dapat mengklik link tersebut dan e-sertifikat dapat diunduh dalam format pdf. 
Tabel 1 Use case scanario mengunduh sertifikat

\begin{tabular}{ll}
\hline Use Case & Mengunduh sertifikat \\
\hline $\begin{array}{l}\text { Participating } \\
\text { Actor }\end{array}$ & Peserta \\
\hline $\begin{array}{l}\text { Flow of } \\
\text { Event }\end{array}$ & $\begin{array}{l}\text { 1. Aktor mengklik menu webinarku } \\
\text { 2. Aktor memasukkan alamat email } \\
\text { 3. Sistem menampilkan informasi } \\
\text { webinar yang akan datang dan } \\
\text { yang sudah diikuti, beserta link } \\
\text { unduh sertifikat. }\end{array}$ \\
& \\
\hline $\begin{array}{l}\text { Entry } \\
\text { Condition }\end{array}$ & $\begin{array}{l}\text { Aktor telah melakukan pendaftaran dan } \\
\text { checkin kehadiran }\end{array}$ \\
\hline Condition & Aktor berhasil mengunduh sertifikat \\
\hline
\end{tabular}

\subsection{Contect Diagram}

Context diagram adalah diagram berupa simbol-simbol grafik yang dapat menggambarkan aliran data pada suatu sistem. Pada diagram ini digambarkan aliran data yang terjadi antara sistem dengan dua entitas luar yaitu peserta dan admin. Context diagram dapat dilihat pada gambar 4 .

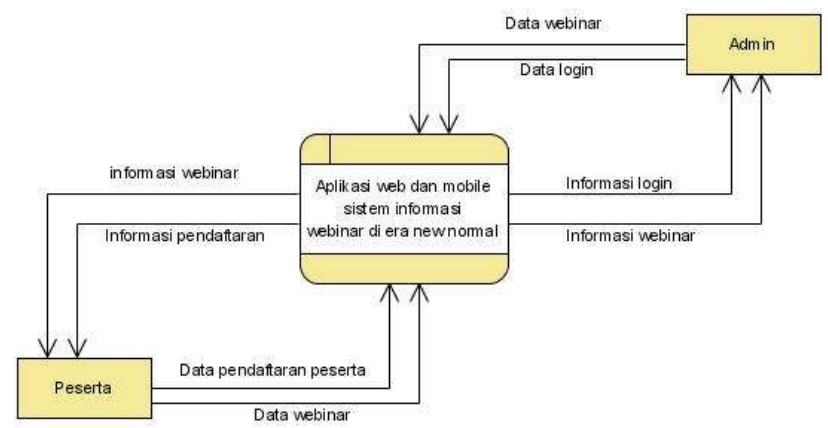

Gambar 4. Context Diagram

\subsection{Perancangan Database}

Perancangan basis data diawali dengan menyusun struktur basis data berdasarkan entitas yang diperlukan dan hubungannya dengan entitas lain. Entitas dan hubungannya dijelaskan pada ERD (Entity Relationship Diagram) untuk merepresentasikan model data dalam sistem. Rancangan database terdiri dari delapan tabel, seperti users, kirim email, peserta, peserta_webinar, webinar, narasumber, narsum_webinar, dan migration. Antara satu tabel dengan tabel yang lainnya memiliki relasi. Rancangan ERD dapat dilihat pada Gambar 6. Masing-masing tabel memiliki atribut dan hubungan dengan tabel lain sesuai kebutuhan sistem.

\subsection{Arsitektur Aplikasi}

Arsitektur aplikasi yang digunakan yaitu MVC (Model View Controller) yang menggunakan metode OOP (Object Oriented Programming) pada framework Laravel. Arsitektur pengembangan aplikasi dapat dilihat pada Gambar 5.

Perancangan aplikasi mobile dibagi menjadi beberapa komponen, yaitu design dan method. Ketika pengguna membuat permintaan ke sistem, maka method akan dijalankan untuk menangani perintah dan mengarahkannya ke routing. Routing membuat panggilan ke controller dan meminta data melalui model. Model kemudian berinteraksi dengan database dan mengirim data ke controller. Selanjutnya controller akan mengirim data dalam bentuk JSON ke method dan ditampilkan oleh design ke halaman user.

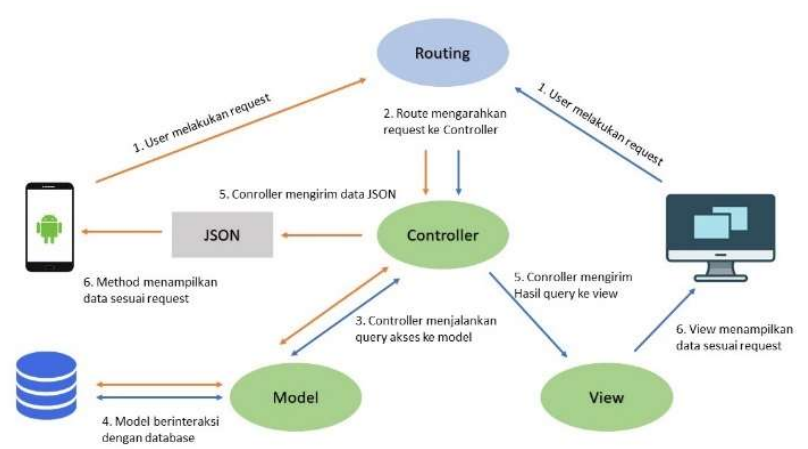

Gambar 5. Arsitektur aplikasi

Berdasarkan Gambar 5, dapat dilihat bahwa perancangan pada aplikasi web menggunakan arsitektur yang memisahkan antara model, view, dan controller. Ketika pengguna membuat permintaan ke sistem, routing diarahkan ke controller sesuai dengan method yang diperlukan. Controller lalu memanggil data melalui model. Selanjutnya model akan berinteraksi dan mengambil data dari database. Data yang diperoleh model akan dikirimkan kembali ke controller untuk kemudian dengan bantuan view, halaman ditampilkan ke user.

Perancangan aplikasi mobile dibagi menjadi dua komponen, yaitu design dan method. Ketika pengguna membuat permintaan ke sistem, maka method akan menjalankan perintah dan mengarahkannya ke routing. Routing membuat pemanggilan ke controller yang sesuai untuk meminta data melalui model. Model berinteraksi dengan database dan mengirim data ke controller. Selanjutnya controller mengirim data berupa format JSON ke method selanjutnya ditampilkan oleh design ke halaman pengguna. 


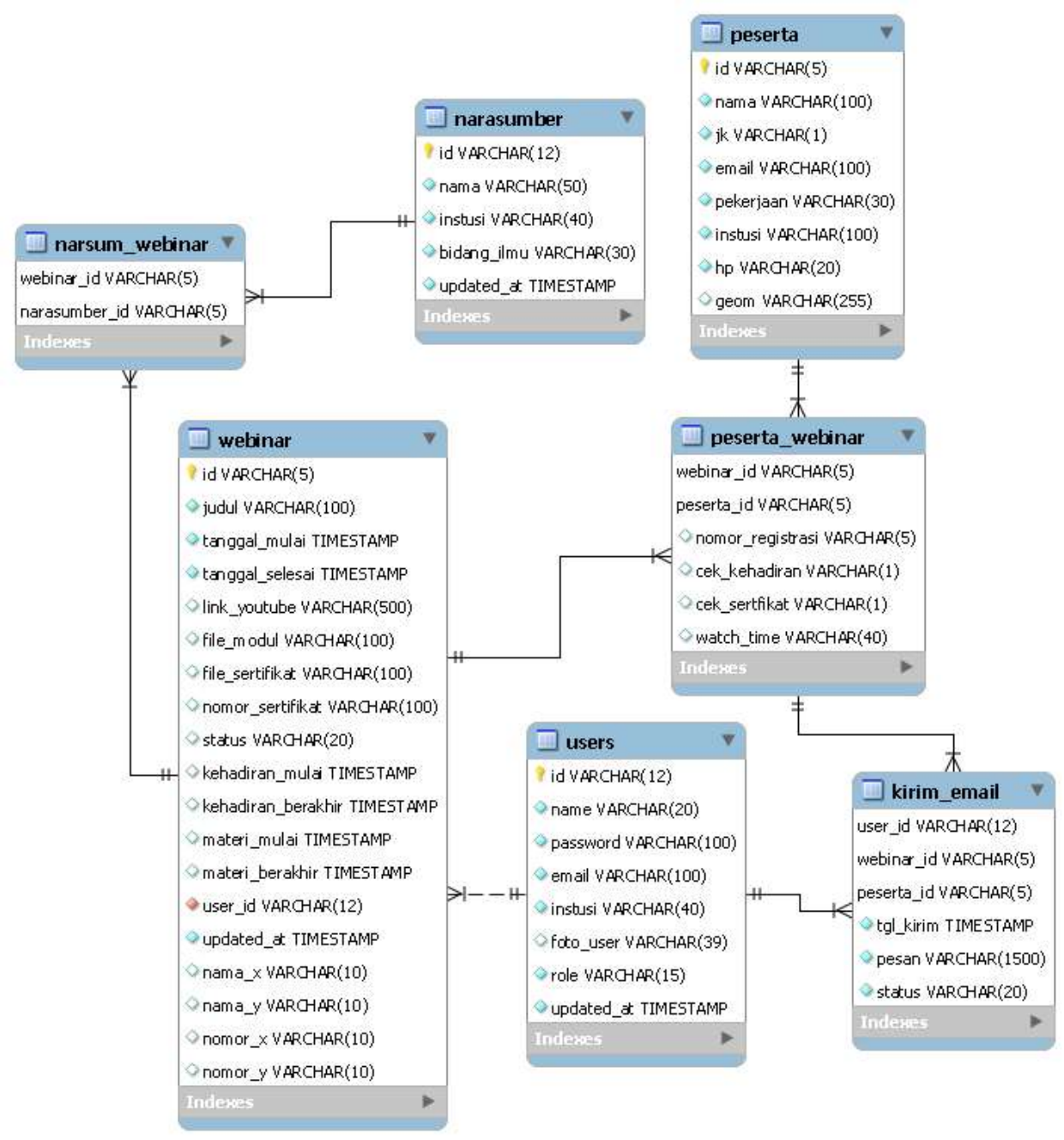

Gambar 6. Entity Relationship Diagram

\subsection{Perancangan Antarmuka Aplikasi Web}

Perancangan antarmuka halaman daftar kegiatan webinar dapat dilihat pada Gambar 4. 9.

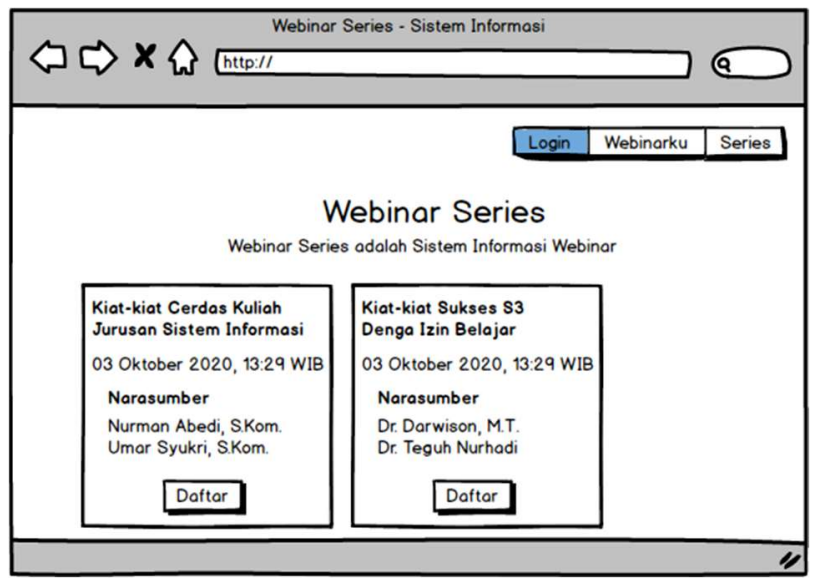

Gambar 7. Perancangan antarmuka halaman daftar kegiatan webinar

Berdasarkan antarmuka halaman daftar kegiatan dari Gambar 7, halaman ini merupakan halaman yang ditampilkan disaat user pertama kali membuka aplikasi sitem informasi webinar. Halaman ini dapat diakses tanpa melakukan login. Halaman daftar kegiatan webinar menampilkan semua kegiatan webinar yang tersedia. Untuk mengikuti kegiatan webinar yang tersedia peserta dapat melakukan pendaftaran dengan mengklik tombol daftar pada webinar yang diinginkan.

\subsection{Perancangan Antarmuka Aplikasi Mobile}

Perancangan antarmuka halaman daftar kegiatan webinar dapat dilihat pada Gambar 8. Halaman ini juga dapat diakses oleh peserta tanpa login ke aplikasi.

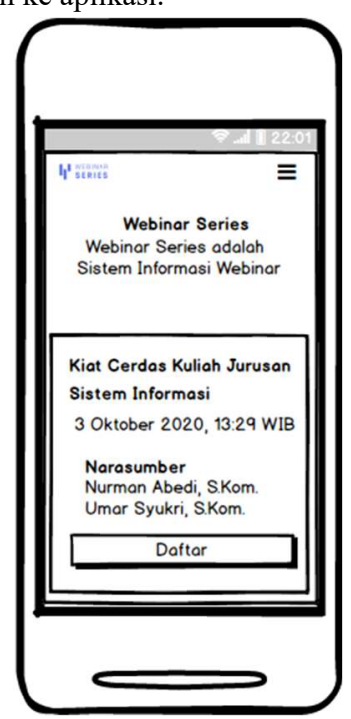

Gambar 8. Perancangan antarmuka halaman daftar kegiatan webinar mobile 


\section{PEMBAHASAN}

Pembangunan aplikasi web menggunakan bahasa PHP versi 7.34.10 dan framework Laravel versi 7.0. Web server yang digunakan adalah apache Laragon versi 3.2.4. Database yang digunakan adalah database MySQL. Pembangunan aplikasi mobile menggunakan Android Studio IDE versi 3.2.1 Android Studio memiliki keunggulan dalam pembuatan antar muka yang lebih sederhana, mudah dan efisien, memiliki dukungan library yang banyak dan mendukung semua perintah pengkodean mobile serta memiliki emulator yang mendukung semua perangkat.

Potongan kode dari controller yang digunakan untuk menampilkan kegiatan webinar dapat dilihat pada gambar 9 .

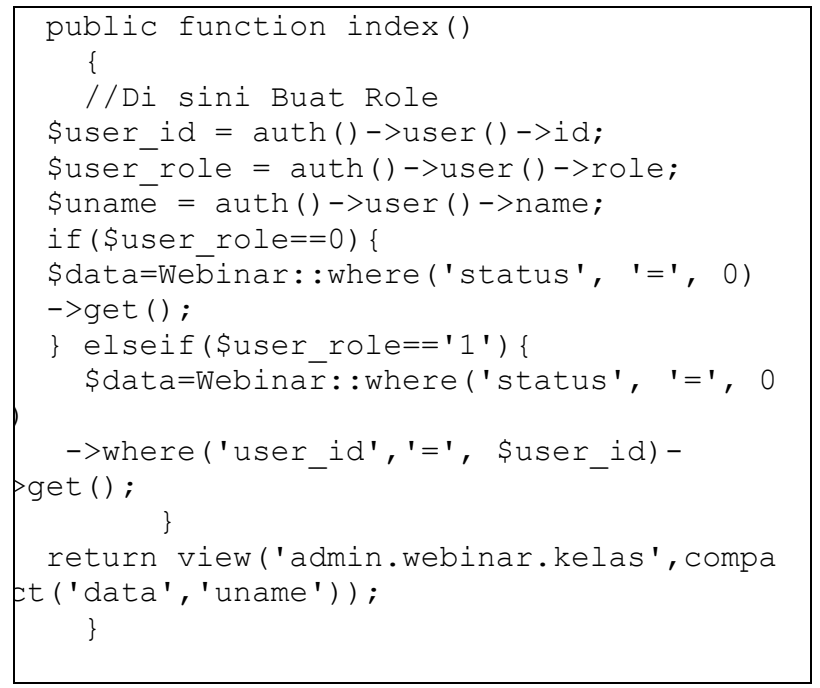

Gambar 9. Kode menampilkan daftar kegiatan webinar

Halaman daftar kegiatan webinar yang tersedia adalah halaman yang ditampilkan ketika pengguna membuka aplikasi pertama kali. Halaman ini berisi daftar kegiatan webinar yang tersedia pada aplikasi web. Tampilan halaman daftar kegiatan webinar yang tersedia dapat dilihat pada Gambar 10.

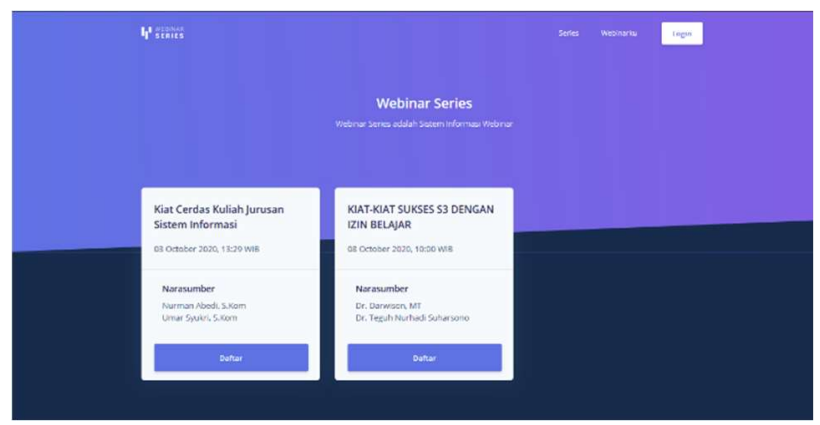

Gambar 10. Tampilan halaman daftar kegiatan webinar

Hasil implementasi halaman daftar kegiatan webinar yang tersedia pada aplikasi mobile dapat dilihat pada Gambar.

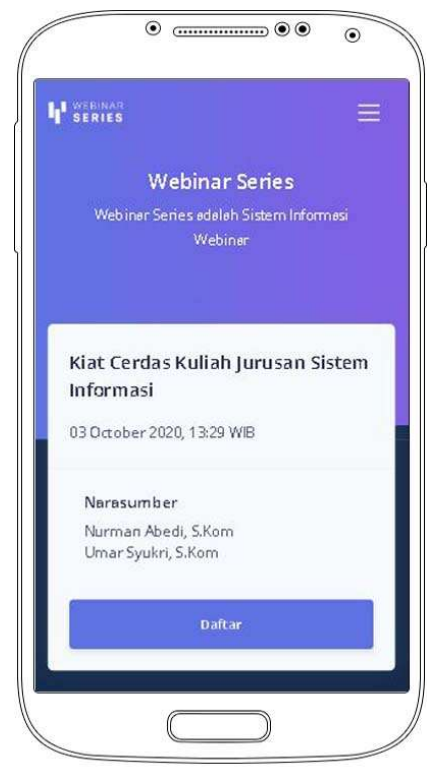

Gambar 11. Tampilan halaman daftar kegiatan webinar mobile

Tahap pengujian sistem adalah prosedur untuk memastikan apakah sistem yang berhasil dibangun sesuai dengan perancangan dari sistem yang telah ditentukan. Pengujian sistem menggunakan metode black box testing, yaitu pendekatan pengujian yang mengkhususkan pada pengecekan ketersediaan fungsional yang telah dirancang. Keunggulan dari pendekatan ini dibandingkan metode white box testing adalah pendekatan ini tidak memerlukan pengetahuan khusus mengenai kode program sistem, sedangkan metode white box testing diperlukan untuk memeriksa kode internal program aplikasi.

Fokus pengujian aplikasi adalah berdasarkan data yang telah didapat dari aplikasi web maupun mobile. Fokus pengujian dapat dilihat pada Tabel 2.

Tabel 2. Fokus pengujian aplikasi

\begin{tabular}{|c|c|c|}
\hline No & $\begin{array}{c}\text { Item } \\
\text { Uji }\end{array}$ & $\begin{array}{l}\text { Detail } \\
\text { Pengujian } \\
\end{array}$ \\
\hline 1 & Mengelola data webinar & $\begin{array}{c}\text { Lihat, tambah, } \\
\text { edit, Hapus }\end{array}$ \\
\hline 2 & Mengelola data narasumber & $\begin{array}{c}\text { Lihat, tambah, } \\
\text { edit, Hapus }\end{array}$ \\
\hline 3 & Mengelola kehadiran & Lihat, tambah \\
\hline 4 & Mengelola waktu unduh file & Lihat, tambah \\
\hline 5 & Upload file & Tambah \\
\hline 6 & Cetak laporan & Tambah \\
\hline 7 & Tambah admin & Tambah \\
\hline
\end{tabular}

Pengujian menambahkan data webinar dilakukan dengan input data webinar pada aplikasi web. Hasil pengujian tambah data webinar dapat dilihat pada Tabel 3. 
Tabel 3. Hasil pengujian tambah data

\begin{tabular}{ll}
\hline \multicolumn{2}{l}{ Kasus dan Hasil Uji (Benar) } \\
\hline Data masukan & $\begin{array}{l}\text { Semua data yang diperlukan pada halaman } \\
\text { tambah data Webinar }\end{array}$ \\
\hline Yang & Sistem akan menampilkan halaman data \\
diharapkan & webinar dan notifikasi Berhasil \\
\hline Pengamatan & Data dapat diinputkan di form tambah data \\
& webinar lalu menekan tombol "Submit" \\
\hline Hasil & Sesuai \\
\hline
\end{tabular}

Pengujian dilakukan dengan masuk ke halaman admin untuk menampilkan menu tambah "webinar" pada halaman dashboard admin. Selanjutnya admin mengklik tombol tambah dan sistem menampilkan form tambah webinar. Pada form tambah webinar user mengisikan data webinar, dan jika penambahan berhasil sistem akan menampilkan halaman daftar webinar dan notifikasi penambahan berhasil.

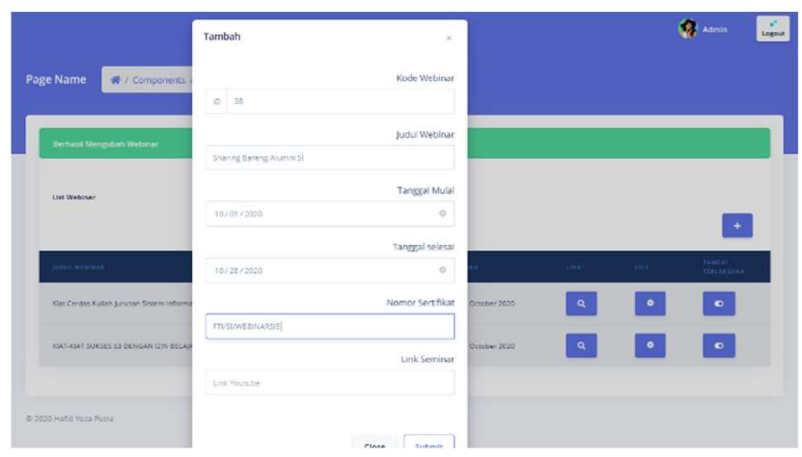

Gambar 12. Tampilan tambah data webinar

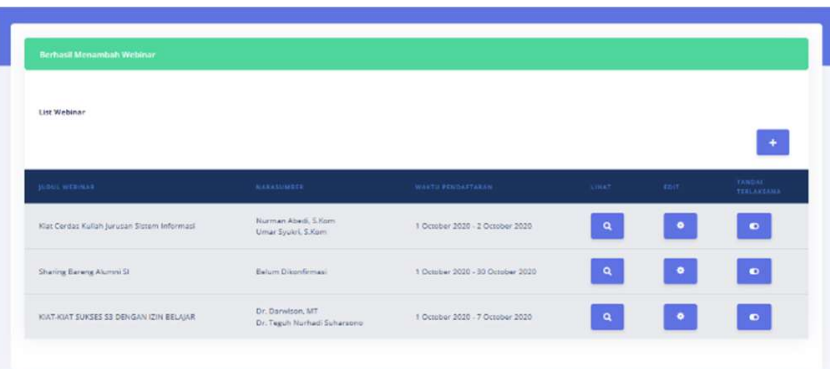

Gambar 13. Tampilan tambah data webinar berhasil

Berdasarkan Gambar 12 dan Gambar 13, input data webinar berhasil dilakukan. Ketika input data berhasil, maka sistem akan menampilkan notifikasi penambahan data webinar berhasil.

Pembuktian yang dilakukan dengan membuat query database dapat dilihat pada Gambar 14. Query select pada tabel webinar untuk membuktikan bahwa data berhasil ditambahkan.

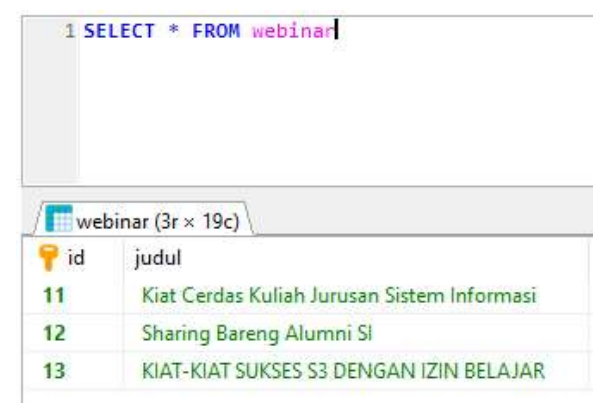

Gambar 14. Query dan hasil menampilkan webinar yang berhasil ditambahkan

Pengujian alternatif dilakukan untuk mengetahui apakah sistem menampilkan notifikasi kesalahan ketika user langsung menekan tombol Submit saat form isian webinar masing kosong. Hasil pengujian input webinar (alternatif) dapat dilihat pada Tabel 4.

Tabel 4. Hasil pengujian input webinar (alternatif)

\begin{tabular}{ll}
\hline \multicolumn{2}{l}{ Kasus dan Hasil Uji (Alternatif) } \\
\hline Data masukan & $\begin{array}{l}\text { Pengguna menekan tombol “Submit” ketika salah } \\
\text { satu atau lebih form webinar masih kosong }\end{array}$ \\
\hline Yang & Sistem akan memberikan notifikasi kesalahan \\
diharapkan & \\
\hline Pengamatan & $\begin{array}{l}\text { Pengguna tidak dapat melakukan } \\
\text { penambahan webinar dan sistem }\end{array}$ \\
& menampilkan notifikasi pesan kesalahan \\
\hline Hasil & Sesuai \\
\hline
\end{tabular}

Pengujian pada aplikasi dengan menekan tombol submit sebelum mengisi field tabel atau saat tabel webinar masih ada yang belum terisi, kemudian akan sistem memberikan notifikasi kesalahan. Hasil pengujian input webinar (alternatif) pada Gambar 15.

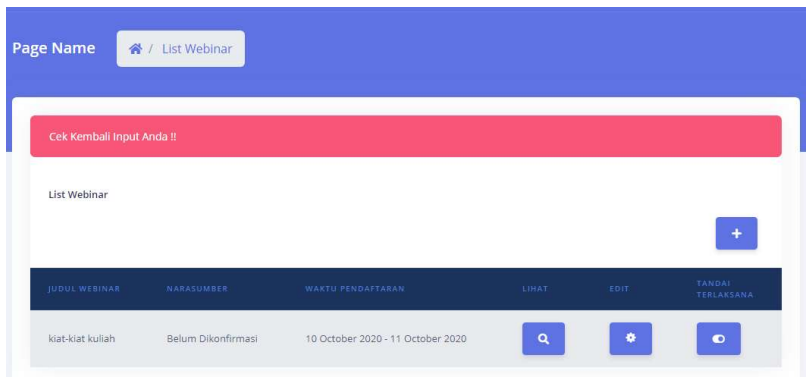

Gambar 15. Tampilan hasil pengujian input webinar (alternatif)

Tahap pengujian pada aplikasi yang telah dibangun, berfokus pada ketersediaan dan kesesuaian antar fungsional dari sistem yang diuji secara manual. Kemudian diperoleh kesesuaian antara perancangan dengan keluaran sistem yang diharapkan. Selama pengujian dilakukan, tidak ditemukan kegagalan pada proses masing-masing fungsional. Pembangunan aplikasi sistem informasi webinar berbasis web dan mobile di era new normal telah berjalan sesuai dengan fungsional yang dirancang. Analisis dari hasil pengujian sistem dapat dilihat pada Tabel 5. 
Tabel 5. Analisis hasil pengujian sistem

\begin{tabular}{cclc}
\hline No & Item Uji & Detail Pengujian & Hasil \\
\hline 1 & $\begin{array}{l}\text { Mengelola data } \\
\text { webinar }\end{array}$ & Lihat, tambah, edit, & Sesuai \\
\hline 2 & $\begin{array}{l}\text { Mengelola data } \\
\text { narasumber }\end{array}$ & Lihat, tambah, edit, & Hapus \\
\hline 3 & $\begin{array}{l}\text { Mengelola } \\
\text { kehadiran }\end{array}$ & Lihat, tambah & Sesuai \\
\hline 4 & $\begin{array}{l}\text { Mengelola waktu } \\
\text { unduh file }\end{array}$ & Lihat, tambah & Sesuai \\
\hline 5 & Upload file & Tambah & Sesuai \\
\hline 6 & $\begin{array}{l}\text { Cetak laporan } \\
7\end{array}$ & Tambah & Sesuai \\
\hline
\end{tabular}

\section{KESIMPULAN}

Pembangunan aplikasi Web dan Mobile Sistem Informasi Webinar di Era New Normal telah berhasil dilakukan. Aplikasi dibangun menggunakan metode waterfall. Laravel merupakan framework php yang digunakan untuk membangun aplikasi web dan aplikasi mobile dibangun dengan Android Studio. Aplikasi memiliki lima belas fungsional dengan dua orang aktor. Hasil pengujian menggunakan metode black box menunjukkan bahwa semua fungsional berjalan sesuai dengan semana mestinya. Aplikasi ini diharapkan dapat menjadi solusi untuk pengelolaan kegiatan webinar di Era New Normal akibat pandemi Covid-19.

\section{DAFTAR PUSTAKA}

[1] P. Y, “APJII: Jumlah Pengguna Internet di Indonesia Tembus 171 Juta Jiwa.” Kompas.Com, Jakarta, 2019.

[2] N. Nuryadi, "Rancang Bangun Aplikasi Website ELearning Pada Smk Respati 1 Jakarta," vol. 4, no. 1, 2018.

[3] B. O. Lubis, "Penerapan Global Extreme Programming Pada Sistem Informasi Workshop, Seminar Dan Pelatihan Di Lembaga Edukasi," Informatika, vol. 3, no. September, pp. 234-245, 2016.

[4] A. I. Mansyur, R. Purnamasari, and R. M. Kusuma, "Webinar Sebagai Media Bimbingan Klasikal Sekolah Untuk Pendidikan Seksual Berbasis Online (Meta Analisis Pedagogi Online)," vol. 4, pp. 26-30, 2019.

[5] J. Ambarita and E. Yuniati, "Indonesian Journal of Instructional Persepsi Masyarakat Terhadap Penggunaan Teknologi Dalam Seminar Online Di Masa Covid-19," vol. 1, pp. 1-8, 2020.

[6] S. K. Wang and H. Y. Hsu, "Use of the webinar tool (elluminate) to support training: The effects of webinarlearning implementation from student-trainers' perspective," J. Interact. Online Learn., vol. 7, no. 3, pp. 175-194, 2008.
[7] A. Verma and A. Singh, "Webinar - Education through digital collaboration," J. Emerg. Technol. Web Intell., vol. 2, no. 2, pp. 131-136, 2010.

[8] A. Verma and A. Singh, "Leveraging Webinar for student learning," Int. Work. Technol. Educ. T4E'09, pp. 86-90, 2009.

[9] P. Lieser, S. D. Taff, and A. Murphy-Haga, "The webinar integration tool: A framework for promoting active learning in blended environments," J. Interact. Media Educ., vol. 2018, no. 1, pp. 1-8, 2018.

[10] D. Oktaviani and S. Hidayat, "Rancang Bangun Portal Seminar Nasional Berbasis Web," Semin. Nas. Telekomun. dan Inform. (SELISIK 2018), no. August, pp. 297-305, 2018.

[11] A. Nugroho, “Aplikasi Web Informasi Dan Registrasi Peserta Seminar, Workshop , Talkshow Pada Acara Seminar Nasional Pengamplikasian Telematika," Semin. Nas. Sist. Inf. Indones., no. November, pp. 115, 2016.

[12] B. Febriadi and P. P. Putra, "Rancang Bangun Aplikasi E-register International Conference Berbasis Online Pada Universitas Lancang Kuning," J-SAKTI (Jurnal Sains Komput. dan Inform., vol. 3, no. 1, p. 132, 2019.

[13] Z. M. N. Nanang Durahman, "Aplikasi Seminar Online (Webinar) Untuk Pembinaan Wirausaha Baru," $J$. Manaj. Inform., vol. 6, no. 2, pp. 111-120, 2019.

[14] W. N. Wk and M. Kom, "Membangun Aplikasi ECertificates Berbasis Web Pada Program Studi Komputerisasi Akuntansi Politeknik Lpkia Bandung," pp. 72-75, 2020.

[15] A. H. Arribathi, S. Saryani, and H. Haris, "Perancangan Aplikasi Smart Seminar Dan Workshop Berbasis Website," J. CERITA, vol. 5, no. 2, pp. 156-164, 2019.

[16] Pressman, R. S., Software Engineering In: $A$ Practitioner's Approach. s.1.: Mc-Graw Hill, 2010.

[17] Susanto, R. \& Adriana, A. D., "Perbandingan Model Waterfall dan Prototyping untuk Pengembangan Sistem Informasi," vol. 14, no.1 , 2016.

\section{BIODATA PENULIS}

Hafid Yoza Putra merupakan civitas akademik di lingkungan Universitas Andalas yang tertarik dibidang Sistem Informasi, Geographical Information System dan Business Intelligence

Hafizah Hanim merupakan civitas akademik di lingkungan Universitas Andalas yang tertarik dibidang Sistem Informasi terutama Sistem Pengambilan Keputusan

Afriyanti Dwi Kartika merupakan civitas akademik di lingkungan Universitas Andalas yang tertarik dibidang Sistem Informasi terutama Audit dan manajemen resiko Sistem Informasi 